\title{
Game Analysis of Oversea Hydropower Investment Income Insurance about the Behavior of both Supply and Demand
}

\author{
Rui Dai \\ Business School, Hohai University, \\ Nanjing, Jiangsu, 210098, China, \\ shichangfeng007@163.com \\ Min Song \\ Business School, Hohai University, \\ Nanjing, Jiangsu, 210098, China, \\ songmin@hhu.edu.com
}

\author{
Feixiang Li \\ Business School, Hohai University, \\ Nanjing, Jiangsu, 210098, China, \\ shichangfeng007@163.com
}

\begin{abstract}
Based on the analysis of income risk of the oversea investment in hydropower, the paper proposes the idea that hydropower enterprises can establish income insurance by distinguishing the features of income risk and other risks, trying to transfer the investment income risk of China's oversea hydropower enterprises from the perspective of insurance. The paper establishes game model of income insurance about the behavior of supply and demand through analysis of the trading strategies of the two sides, deducing the condition that oversea hydropower enterprises purchase the income insurance and insurance companies supply it. A theoretical foundation is laid for the designing and pricing income insurance in the following study
\end{abstract}

Keywords- Oversea hydropower investment; Investment income insurance; Game analysis; Supply; Demand

\section{INTRODUCTION}

According to the needs of the national energy strategy, China's hydropower enterprises are looking for hydropower resources in the world to invest hydropower for preserving and increasing the value of capital, thus forming the economic behavior of China's oversea investment in hydropower. During oversea investment in hydropower, China's hydropower enterprises develop water by way of joint ventures or wholly-owned to obtain long-term earnings or oversea power resources. And they can gain profits and enjoy ownership or management rights of the hydropower project according to the sale in the electric power market.

The process of oversea investment in hydropower is much more complicated than the domestic hydropower investment behavior due to border. Compared with the domestic hydropower project, the purposes of oversea hydropower investment are diversified, the export of domestic hydropower equipment and access to power resources are also considered in addition to investment income; and at the same time, foreign investment in hydropower faces a more complex environment, taking greater risks. Yescombe (2002) believed that various risks would be exposed if effective risk management measures were not taken, project sponsors and loans would also feel financial frustrated. Therefore, sponsors and lenders should fully assess the potential risks of the project before entering contract negotiations (Hoffman, 2001). If the risks are difficult to accept or can not be transferred, they should withdraw the project (Esty, 2003). In other words, sponsors and lenders only enter the project under the condition that project risk can be transferred appropriately and make the investment conditions profitable. Thus, risk management and risk transfer is essential for enterprises to invest in oversea hydropower.

At present, the general risk can be managed through reducing, sharing, sharing. Especially as one of the most effective means of risk management by far, insurance has played an important role in oversea hydropower investment and construction. Much more mature insurance products are listed as flows: mandatory engineering insurance includes construction- all- risks insurance, Erection- all- risks insurance, social insurance (such as personal accident insurance, employers liability insurance, etc.), motor vehicle insurance, 10-year liability insurance and liability insurance, professional liability insurance; and voluntary business insurance includes international cargo transportation insurance, domestic cargo transportation insurance, property insurance, liability insurance, political risk insurance and rate insurance.

However, income risk is worth noting among so many risks and there is still no way to transfer it. Income risk mainly refers to oversea investment in hydropower project, income is at risk when the cash is insufficient to meet the cost of the project and the repayment of project debt, and project sponsor is unable to obtain the expected return. According to the main source of income risk, income risk can be called " risk of power generation and electricity pricing " or " operational risk ".

The specificity of BOT project is that the project company must bear all risks of the project during the period of the franchise. Therefore, a long-term risk management plan as well as an integral seamless insurance plan is needed. The project company should also take rigorous risk assessment, do timing inspection work during the performance of the contract, and imply a complete risk-controlling countermeasure. What's more, the 
insurance premium, insurance conditions and the ability of risk handling of the insurance company the reinsurance company should be assessed by the insurance specialist.

General insurance: Includes engineering all risks, personal accident insurance, third party liability insurance, freight insurance, and so on.

Professional liability insurance: To bear the risk of each professional contractor during the implementation of the project. This kind of insurance is not a common one in a single project, but it covered all the risks of all the independent contractors in the way of yearly guarantee slips. Therefore, professional liability insurance should be independent of other insurances but throughout the construction and operation period.

The insurances in the construction period include the following ones.

Transportation insurance (both inland and marine): Underwrite the risk loss from manufacturing factory of the required equipment to the site of the project;

Subsequent transportation insurance: The subsequent loss in operating caused by the losses while transporting the equipments;

Contractors all risks/ installing all risks: The loss occurred in the construction and trial operation period, as well as the insurance on the liability risk within this period;

Insurance on expected profit loss in operation: The profit loss because of the overdue operation caused by the risks in cargo transportation and engineering construction and during the construction period, as well as the risks occurred during the trail operating period;

Purchasing credit insurance: It is generally a payment protection for the equipment suppliers/vendors.

Domestic and foreign scholars has not paid due attention to income risk of oversea hydropower investment. At present, the research is mainly concentrated on the financing model, project risk and financing guarantees about project financing and project risk. In so many project risk literatures, there is lack of special research on oversea hydropower BOT project financing, not to mention indepth study of income risk. Most scholars generally focus on the macroscopic natural, economic, social, political risks, but micro-level project income risk has received less attention.

Oversea investment in hydropower is carried out in order and insurance products are required objectively covered in each phase of the project. Given the current oversea investment in hydropower insurance is set mainly in the construction phase of the project and the realization of project income is vital for project sponsors, a possible avenue of transferring income risk is in the operational phase. Insurance company can provide a certain level of insurance on income from oversea hydropower projects. At present, foreign countries have started the insurance mechanism such as power reserve capacity insurance in the power market. In Australia, many intermediary institutions led by banks act as middlemen in power market transaction, guaranteeing the corresponding price between retailers and suppliers. As Australia's largest investment bank, Macouarie Bank has developed intermediary business such as market insurance to the electricity market, providing price guarantees for retailers and suppliers to reduce operational risks.
II. GAME ANALYSIS OF OVERSEA HYDROPOWER INVESTMENT INCOME INSURANCE

After making clear underwriting process of income insurance, this paper will explain trading strategies between sides of insurance transaction based on expected utility theory. Expected utility theory is one of the most perfect decision theories in economics. The theory states that if individual is able to use the expected utility theory of estimation of all results as a set of consistent utility, then expected utility maximization can be used as a standard, and decision-making of sharing individual's true preference can be formed ultimately. The scheme results are sorted according to the size of expected utility based on this idea. As a rational person, he usually chooses the maximum utility program. In this paper, expected profit is used in place of expected utility, for oversea hydropower investment enterprises and insurance companies, to pursuit maximization of the expected utility is to pursuit maximization of the expectation profit.

First put forward the hypothesis of condition and variable settings of the game model before conducting behavior game:

Project manager of the oversea investment in hydropower is rational economic man, and there is no other source of income of the project in addition to the hydropower operating income.

There exists information asymmetry between the insurance company and the oversea hydropower enterprises, there are differences in the quantity and quality of the information that mastered by the parties of the transaction.

Operating income of oversea hydropower investment projects exists risk and risk-free, the project manager has to choose whether or not to insure the rights, there also exists the possibility of operating income insurance for insurance companies.

Investment capital of oversea hydropower projects is $W_{0}$, amount of external financing is $\boldsymbol{C}$, interest rate is $r$. To simplify the model, we do not consider the time value of money invested into the project.

Each variable in the model is set as follows: oversea investment in hydropower projects faces income risk, the project income is $\mathrm{R}$ when the risk does not occur, loss rate of project income is b when the risk occurs, $0 \leq b \leq 1$; the project income $(\mathrm{R})$ has clearly a positive correlation with the occurrence probability of risk (p), meaning that the higher investment risk, the higher compensation for additional income. Premiums for income insurance which oversea hydropower project investment is $\delta$, the loss amount is I.

The main actors between supply and demand of Income insurance refer to enterprises which invest in oversea hydropower and insurance companies which provide income insurance. They are independent actors with their own economic purposes in insurance transaction, they can be called "rational economic man" who pursuit profit maximization of their own. Description of selection strategy and expected revenue in the transaction process is as follows: 
A. The choice strategies of oversea hydropower enterprise include: purchase income insurance or not:

\section{1). Not purchase}

If oversea hydropower enterprise does not purchase income insurance, the profit of enterprise when income risk does not occur is: $Y_{1}=R-W_{0}$; while the profit of enterprise when income risk occurs is: $Y_{1}^{\prime}=(1-b) R-W_{0}$. Thus, the expected profit of oversea hydropower enterprise is:

$$
\begin{aligned}
E\left(U_{1}\right) & =Y_{1} \times(1-p)+Y_{1}^{\prime} \times p \\
& =\left(R-W_{0}\right) \times(1-p)+\left[(1-b) R-W_{0}\right] \times p \\
& =R-b p R-W_{0}
\end{aligned}
$$

\section{2). Purchase}

If oversea hydropower enterprise purchases income insurance, the profit of enterprise when income risk does not occur is: $Y_{2}=R-W_{0}-\delta$; while the profit of enterprise when income risk occurs is: $Y_{2}^{\prime}=(1-b) R-W_{0}-\delta+I$. Thus, the expected profit of oversea hydropower enterprise is:

$$
\begin{aligned}
E\left(U_{2}\right) & =Y_{2} \times(1-p)+Y_{2}^{\prime} \times p \\
& =\left(R-W_{0}-\delta\right) \times(1-p)+\left[(1-b) R-W_{0}-\delta+I\right] \times p \\
& =R-b p R-W_{0}-\delta+p I
\end{aligned}
$$

B. The choice strategies of insurance company include:

operating income insurance business or not:

\section{1)Operate}

If insurance company operates insurance, the profit of insurance company when income risk does not occur is: $Y_{3}=N \times \delta-M(N, t)$; while the profit of insurance company when income risk occurs is: $Y_{3}^{\prime}=N \times \delta-M(N, t)-c \times N \times I$, where $c$ is the percentage of enterprises those income risk happened accounting for the total number of enterprises those insure, $0 \leq c \leq 1$. Management cost of insurance company during operating the income insurance is $M(N, t)$, where $M$ is related to insurance quantity $\mathrm{Q}$ and other factors $\mathrm{t}$.

As a result, the expected profit of insurance company operating income insurance is:

$$
\begin{aligned}
E\left(U_{3}\right) & =Y_{3} \times(1-p)+Y_{3}^{\prime} \times p \\
& =[N \times \delta-M(N, t)] \times(1-p)+[N \times \delta-M(N, t)-c \times N \times I] \times p \\
& =N \times \delta-M(N, t)-c \times p \times N \times I
\end{aligned}
$$

\section{2)Not operate}

When insurance company does not operate income insurance, the expected profit of insurance company is 0 , $E\left(U_{4}\right)=0$

\section{INCOME INSURANCE COVERAGE OF OVERSEA HYDROPOWER INVESTMENT BASED ON BEHAVIOR GAME}

\begin{tabular}{|c|c|c|}
\hline \multirow{2}{*}{$\begin{array}{l}\text { hydropower } \\
\text { enterprise }\end{array}$} & \multicolumn{2}{|c|}{ Insurance company } \\
\hline & $\begin{array}{l}\text { Operating income } \\
\text { insurance }\end{array}$ & $\begin{array}{c}\text { No-operating income } \\
\text { insurance }\end{array}$ \\
\hline Insure & $\begin{array}{l}R-b p R-W_{0}-\delta+p I \\
N \times \delta-M(N, t)-c \times p \times N \times I\end{array}$ & $\begin{array}{c}R-b p R-W_{0} \\
0\end{array}$ \\
\hline Not insure & $\begin{array}{l}R-b p R-W_{0}, \\
0\end{array}$ & $\begin{array}{c}R-b p R-W_{0} \\
0\end{array}$ \\
\hline
\end{tabular}

According to the above analysis of the trading strategy, the behavior game relationship of insurance company with oversea hydropower enterprise is as shown in Tab.1.

projects decreasing during the insurance period. The rate of premiums can be reduced as more enterprises participate in insurance.
TABLEI. GAME MODEL OF INSURANCE ABOUT THE BEHAVIOR OF SUPPLY AND DEMAND

From the behavior game procedure as shown in Tab .1, some interesting results can be found and are discussed as the follows.

1)If Hydropower enterprise insures the project, and insurance company also operates insurance, then regardless of income risk, the expected profit of hydropower enterprise is $R-b p R-W_{0}-\delta+p I$; Expected profit of insurance company is $N \times \delta-M(N, t)-c \times p \times N \times I$

2)If the hydropower enterprise is willing to insure the project, but the insurance company does not operate the insurance which leads the insurance behavior failing to occur, the expected profit of project is $R-b p R-W_{0}$ Insurance company does not operate this insurance, so the expected profit is 0 .

3)If the hydropower enterprise does not insure, and the insurance company is willing to operate insurance business, the expected profit of hydropower enterprise is $R-b p R-W_{0}$; Expected profit of insurance company is 0 .

4)If the hydropower enterprise does not insure, and the insurance company does not operate insurance business, the expected profit of hydropower enterprise is $R-b p R-W_{0}$; Expected profit of insurance company is 0 .

From this game model above, we can see only the following two conditions are met can a rational enterprise investment in oversea hydropower purchase income insurance and insurance company operate income insurance:

$$
\begin{aligned}
& R-b p R-W_{0}-\delta+p I \geq R-b p R-W_{0} \text {, i.e., } p I-\delta \geq 0 \\
& N \times \delta-M(N, t)-c \times p \times N \times I \geq 0 \text {,i.e., } \delta \geq M(N, t) / N+c \times p \times I \\
& \text { As a result, } \quad p I \geq \delta \geq M(N, t) / N+c \times p \times I
\end{aligned}
$$

Only $\delta$ is in this interval will the insurance company be willing to operate income insurance, will the hydropower enterprise buy income insurance. When $\delta$ is too small, the insurance company faces a loss situation; When $\delta$ is too large, the hydropower enterprise has no interest in income insurance because of the high cost of insurance.

In addition, from Equation (6) we can see, in the process of determining rate of premiums, the insurance premiums can be reduced as the quantity of loss. 


\section{CONCLUSIONS AND FURTHER STUDY}

According to analysis of the trading strategies, the paper establishes game model of income insurance about the behavior of supply and demand, deducing the condition that oversea hydropower enterprises purchase the income insurance and insurance companies supply it. A theoretical foundation is laid for the designing and pricing income insurance in the following study.

Income insurance contract is a carrier of insurance transaction between insurance company and oversea hydropower enterprise, design of income insurance contract not only affects requirements of income insurance, but also affects coverage of damage. In a competition insurance market with no information asymmetry, as long as the insured is able to get the same level of utility from the purchase of insurance contract, then he is likely to buy the insurance contract. However, an insurance market with information symmetry does not exist, because the insured has private information can be provided to the insurer so easily. Design of the insurance contract is closely related to the information asymmetry of insurance market. If insurance customers suffer a loss accident, the form of the optimal insurance contract will be affected.

Insurance pricing has to adjust to the specific circumstances of the insurance. The actual price of insurance should be set based on the full rate in different market environment, the setting process should take the rate of capital return, market share and other factors into consideration. The first step of insurance pricing is actually ratemaking,income insurance has not been introduced in the insurance market, so the core issue of Income insurance is ratemaking problem.

\section{REFERENCES}

[1] Bollerslev, T., "Generalized Autoregressive Conditional Heteroskedasticity”. Journal of Econometrics 1986 , pp.307-327

[2] Danielsson, J, “ Stochastic volatility in asset prices: estimation with simulated maximum likelihood," Journal of Econometrics 1994, pp. 375-400

[3] Economic analysis of investment operations: analytical tools and practical applications, World Bank Publications, 2001

[4] Betz J, Hanif M., "The formation of preferences in two-leve games: An analysis of India's domestic and foreign energy policy". GIGA working papers, 2010

[5] Woodhouse E J. Obsolescing Bargain Redux,Foreign Investment in the Electric Power Sector in Developing Countries", NYUJ Int'1. L. \& Pol., 2005, pp.121

[6] Yuan Z, "Causes and Prevention of Moral Risk of Entrusted Audit in Construction Project," Journal of Huazhong Agricultural University (Social Sciences Edition), vol. 6, 2013, pp. 19-24.

[7] Flåm S D, Ermoliev Y, "Investment Uncertainty, and Production Games," CESifo Working Paper, 2004.

[8] Wilkins M, Wilkins M, "The history of foreign investment in the United States”, Harvard University Press, 2009, pp. 1914-1945.

[9] Neves M F, Pinto M J A, "Analysis of the relationship between public regulation and investment decisions for disaster risk reduction in the agribusiness sector". 2013.

[10] Kokouma D M S, Xu K, "Attracting Chinese Foreign Direct Investment (FDI) to Africa: Determinants and Policies-The Case of Guinea," International Journal of Financial Research, vol. 4, 2013,

pp.4-14 